\title{
Impact of oil contamination of grey forest soil on its nutrient status and plant safety
}

\author{
Regina A. Osipova ${ }^{1, *}$, Minnegali Yu. Gilyazov ${ }^{1}$, Svetlana Zh. Kuzhamberdieva ${ }^{1}$ and Bahytbek B. Abzhalelov ${ }^{2}$ \\ ${ }^{1}$ Kazan State Agrarian University, Kazan 420015, Russia \\ ${ }^{2}$ Korkytata State University, Kyzylorda 120014, Republic of Kazakhstan
}

\begin{abstract}
The study was carried out in the Republic of Tatarstan (Volga Federal District of the Russian Federation) in grey forest middle loamy soil with weak acid reaction of the medium, low humus content, increased content of labile forms of phosphorus and potassium. The soil was deliberately contaminated with oil at a dose of $251 / \mathrm{m}^{2}$. There is close positive linear relationship $\left(R_{2}=0.845\right)$ between the amount of bens(a)pyrene (BP) and petroleum substances in soil. The BP content in oil-contaminated horizons (0-15, $15-30,30-45 \mathrm{~cm})$ of soil exceeded the maximum allowable concentration by 10.5-19.5 times that demonstrates a serious threat to vegetable products growing on oil-contaminated lands. Due to oil contamination, the content of most labile forms of nutrients (N, P, K, B, Mo, Zn) decreased and others remained unchanged $(\mathrm{Cu}, \mathrm{Co})$ or increased $(\mathrm{Mn})$. At the same time, these changes were not so significant, because the groups of soil supply with labile forms of nutrients, except phosphorus and potassium, did not change under the influence of oil.
\end{abstract}

\section{Introduction}

Oil and oil products remain the most common environmental pollutants, including the soil cover [1-3]. In the Russian Federation, the damage from oil pollution increased from 2018 billion to 5.1 billion rubles compared to 2017 [4]. This problem is particularly relevant for oil producing regions, including the Republic of Tatarstan (RT) that produced more than 3.3 billion tons of oil. The soil of oil contaminated lands loses fertility for many years and leave agricultural circulation $[2,5]$.

The most important elements of soil fertility, including those contaminated with oil, which largely determine the value and quality of crop production, include soil supply with absolutely necessary macro- and microelements and the content of toxic substances in soil.

The information on the nature of the effect of oil and petroleum products on the content of labile forms of nutrients is contradictory: while some researchers report that there is no significant decrease or even slight increase in the content of labile forms of nitrogen, phosphorus and potassium in contaminated soils [6-8], the others argue the opposite [9-11].

Among organic toxicants, the most common and dangerous is bens(a)pyrene (BP) [12, 13], which is part of the first class of hazard. There are natural and technogenic sources of BP, but its vast majority enters the environment as a result of human activity. Oil and petroleum products, which contain a large amount of BP, serve an extremely serious source of environmental pollution, but even more of it is formed while burning. There is not enough information on the accumulation of bens(a)pyrene in oil-contaminated soils [14].

The purpose of the study is to assess the effect of oil pollution on the content of labile forms of basic nutrients belonging to the group of absolutely necessary macroand microelements, as well as bens(a)pyrene in grey forest soil.

\section{Materials and Methods}

The study was carried out on the experimental field of Kazan State Agrarian University located in the agroproduction zone of Predkamye of the Republic of Tatarstan. This zone occupies the northern part of the republic: from the south-west of Predkamye it is limited by the Volga River, from the south - by the Kama River. In terms of its relief it is a low hillside plain, the highest heights of which reach $240 \ldots 280 \mathrm{~m}$. Its area is 21.8 thousand $\mathrm{km}^{2}$, which is $32.2 \%$ of the total area of the Republic of Tatarstan. The majority $(67 \%)$ of the agricultural land of Predkamye is located on various subtypes of grey forest soils.

The experimental site is characterized by grey forest middle loamy subacid soil $(\mathrm{pH}=5.4)$ typical for Predkamye of the RT. Before oil contamination the 0-30 cm soil layer had low humus content $(2.9 \%)$, increased content of labile forms of phosphorus $(125 \mathrm{mg} / \mathrm{kg})$ and potassium $(122 \mathrm{mg} / \mathrm{kg})$.

Field experiment plots represent bottomless boxes located at a depth of $30 \mathrm{~cm}$. The area of the plots is

Corresponding author: Reginka300894@mail.ru 
$0.50 \mathrm{~m}^{2}$, the width of a protective belt is $1 \mathrm{~m}$. The replication of the experiment is quadruple.

The soil was once contaminated with commercial oil by flooding from the surface. Commercial oil prepared at the Oil and Gas Production Department (OGPD) of TATNEFT oil company was used to contaminate the soil. It was characterized by the following parameters: density at a temperature of $20{ }^{\circ} \mathrm{C}-0.872 \mathrm{~g} / \mathrm{cm}^{3}$, water content $-0.05 \%$, mass fraction of sulphur $-1.93 \%$, concentration of chloride salts $-18 \mathrm{mg} / \mathrm{dm}^{3}$. The soil was deliberately contaminated at a rate of 251 of commercial oil per $1 \mathrm{~m}^{2}$. This dose, as our previous studies showed [2], corresponds to the average level of pollution.

Agrochemical analyses of soil were made at the Department of Agrochemistry and Soil Science of Kazan SAU, at the Center of Agrochemical Service Tatarsky and the Center of Hygiene and Epidemiology of the Republic of Tatarstan using the following standard methods: humus according to GOST 26213-91, exchange acidity according to GOST 26484-85, labile forms of phosphorus and potassium according to GOST 26207-91, labile forms of microelements according to GOST R 50682-94 (Mn), GOST R 50684-94 (Cu), GOST R 50686-94 (Zn), GOST R 50687-94 (Co), GOST R 50688-94 (B), GOST R 50689-94 (Mo), alkalihydrolyzable nitrogen according to Kornfield, bens(a)pyrene according to high-performance liquid chromatography using Fluorat-02liquid analyzer as per M 03-04-2002. Statistical processing of experimental data was carried out by the dispersion analysis [15] using Microsoft Excel 97. The correlation regression analysis was performed using the program Statistica ver. 5.5 A for Windows.

\section{Results and Discussion}

The effect of oil pollution, which occurred 16 days prior to soil sampling and which was identified as fresh contamination, on the content of labile forms of nitrogen, phosphorus and potassium is shown in Table 1.

Table 1. Effect of oil pollution* on the content of labile forms of nitrogen, phosphorus and potassium in $0-30 \mathrm{~cm}$ layer of grey forest soil

\begin{tabular}{|c|c|c|c|}
\hline \multirow{2}{*}{ Soil } & \multirow{2}{*}{$\begin{array}{l}\text { Alkali-hydrolyzable } \\
\text { nitrogen according } \\
\text { to Kornfield }\end{array}$} & \multicolumn{2}{|c|}{\begin{tabular}{|c|} 
Labile forms according to \\
Kirsanov \\
\end{tabular}} \\
\hline & & phosphorus & potassium \\
\hline $\begin{array}{c}\text { Uncontaminated } \\
\text { (control) }\end{array}$ & $\frac{158 * *}{100}$ & $\frac{126}{100}$ & $\frac{121}{100}$ \\
\hline Oil-contaminated & $\frac{102}{65}$ & $\frac{98}{78}$ & $\frac{97}{80}$ \\
\hline $\mathrm{LSD}_{05}(\mathrm{mg} / \mathrm{kg})$ & 10 & 6 & 6 \\
\hline
\end{tabular}

Note: * - soil was sampled 16 days after contamination; ** in numerator in $\mathrm{mg} / \mathrm{kg}$ of soil, in denominator - in percentage relative to control.

In uncontaminated soil, the content of alkalihydrolyzable nitrogen according to Kornfield, labile forms of phosphorus and according to Kirsanov were 158, 126 and $121 \mathrm{mg} / \mathrm{kg}$ respectively, which corresponds, according to [16], to the average (N) and increased availability (RC) of soil with these macroelements.

Oil pollution of grey forest soil reduced the content of labile forms of all three macroelements. Particularly noticeable was the decrease in the content of labile nitrogen in the oil-contaminated soil: if the content of alkali-hydrolyzable nitrogen decreased by $35 \%$ compared to the control, the content of labile forms of phosphorus and potassium - by 22 and $20 \%$. In our view, the detected decrease in the content of labile forms of soil nutrients from oil pollution is primarily caused by the coating of soil particles with an oil film, which makes it difficult to transfer nutrients into the soil extract.

Table 2 shows the nature of the effect of oil pollution on the content of labile forms of microelements, which play an important role in regulating the growth and development of plant bodies.

The content of labile forms in uncontaminated soil was estimated as the average for all the studied microelements. Soil samples taken 16 days after contamination showed more manganese and less boron, molybdenum and zinc. In terms of the content of labile forms of copper and cobalt, the oil-contaminated soil did not differ from the control (uncontaminated) soil. Among the three microelements, which content decreased due to fresh oil pollution, the boron content changed most significantly.

With respect to control, the content of labile boron decreased by $35 \%$. The decrease in the content of labile forms of boron, molybdenum and zinc in the oilcontaminated soil is likely to be explained by the difficulty of their displacement by the extracting solution due to the coating of soil particles with an oil film. A more pronounced decrease in the content of labile boron due to oil may be caused by the fact that distilled water is used to displace it, while for other microelements stronger extracts are used - acid or salt solutions.

Table 2. Effect of oil pollution* on the content of labile forms of microelements in grey forest soil

\begin{tabular}{|c|c|c|c|c|}
\hline \multirow[b]{2}{*}{ Microelements } & \multirow{2}{*}{\begin{tabular}{|c|}
$\begin{array}{c}\text { Uncontaminated } \\
\text { soil (control), } \\
\mathbf{m g} / \mathbf{k g}\end{array}$ \\
\end{tabular}} & \multicolumn{2}{|c|}{ Contaminated soil } & \multirow{2}{*}{$\begin{array}{c}\mathrm{LSD}_{05} \\
(\mathrm{mg} / \mathrm{kg})\end{array}$} \\
\hline & & $\mathrm{mg} / \mathrm{kg}$ & $\%$ to control & \\
\hline \multicolumn{5}{|c|}{ Contamination period $* *-16$ days } \\
\hline B & 0.71 & 0.46 & 65 & 0.06 \\
\hline Mo & 0.17 & 0.14 & 82 & 0.02 \\
\hline $\mathrm{Mn}$ & 49.0 & 58.0 & 118 & 6.0 \\
\hline $\mathrm{Cu}$ & 3.1 & 3.0 & 97 & $\mathrm{~F}_{\mathrm{f}}<\mathrm{F}_{05}$ \\
\hline $\mathrm{Zn}$ & 4.1 & 3.4 & 83 & 0.7 \\
\hline Co & 1.5 & 1.5 & 100 & $\mathrm{~F}_{\mathrm{f}}<\mathrm{F}_{05}$ \\
\hline \multicolumn{5}{|c|}{ Contamination period -365 days } \\
\hline B & 0.62 & 0.48 & 77 & 0.06 \\
\hline Mo & 0.16 & 0.14 & 88 & $\mathrm{~F}_{\mathrm{f}}<\mathrm{F}_{05}$ \\
\hline Mn & 51.0 & 57.0 & 112 & 3.0 \\
\hline $\mathrm{Cu}$ & 3.1 & 3.1 & 100 & $\mathrm{~F}_{\mathrm{f}}<\mathrm{F}_{05}$ \\
\hline $\mathrm{Zn}$ & 4.2 & 3.6 & 86 & 0.3 \\
\hline Co & 1.6 & 1.6 & 100 & $\mathrm{~F}_{\mathrm{f}}<\mathrm{F}_{05}$ \\
\hline
\end{tabular}

Note: $*$-deliberate oil pollution is calculated at $25 \mathrm{l} / \mathrm{m}^{2}$; ** time from the moment of contamination to soil sampling. 
Manganese was the only microelement among those studied, which labile form content increased due to oil contamination, and the labile form content increased by $18 \%$ relative to the reference level. This may be caused by anaerobic conditions in the oil-contaminated soil as a result of contamination of soil particles with an oil film.

In general, although the content of four of the six microelements in the oil-contaminated soil has changed significantly, the content of labile forms of neither microelement in grey forest soil under the influence of oil pollution has not moved to another group of reserves.

In soil samples taken one year after contamination, the content of labile forms of the three microelements (molybdenum, copper, cobalt) in the control and contaminated soils was almost the same, although a statistically unreliable decrease in molybdenum in the contaminated soil remained.

As in the first observation period, the contaminated soil differed from the control by lower content of labile forms of boron and zinc, but higher content of manganese. Comparing the data of two periods of determination of the content of labile forms of microelements, it can be noted that the influence of oil on the supply of microelements in old-contaminated soil was less relief-bound. This circumstance, in our opinion, can be explained by the degradation of oil substances over the past year and the reduction of the blocking effect of the oil film by the transition of microelements' ions from soil particles to extract.

As already mentioned, among the many toxic substances of great concern to specialists and the public, a particular place is taken by bens(a)pyrene with its mutagenic and carcinogenic activity $[12,13]$. Table 3 shows the results of the analysis of soil samples collected in one year after oil pollution from 0-15, 15-30 and 30-45 cm layers.
Bens(a)pyrene is found both in control and oilcontaminated soil. Its content in uncontaminated soil varied from 0.7 to $5.30 \mu \mathrm{g} / \mathrm{kg}$ of soil, which is $3.8-28.6$ times lower than the maximum permissible concentration (MPC). According to a number of authors $[17,18]$, the natural level of BP in soils varies from 5 to $10 \mu \mathrm{g} / \mathrm{kg}$ of soil, i.e. its content in our uncontaminated soil roughly corresponds to the lower value of the background level.

The nature of BP distribution according to the profile of uncontaminated soil seems quite interesting. As can be seen, the minimum amount of BP is found in the upper 0-15 cm layer of soil, and the maximum amountat a depth of 30-45 cm. It is interesting that in the 30-45 $\mathrm{cm}$ layer of background soil there is a small amount of oil substances, about the nature of origin of which it is difficult to judge clearly.

Table 3. Distribution of bens(a)pyrene along the profile of oilcontaminated grey forest soil*

\begin{tabular}{|c|c|c|c|c|}
\hline Soil & $\begin{array}{c}\text { Layer, } \\
\text { cm }\end{array}$ & $\begin{array}{c}\text { Bens(a) } \\
\text { pyrene } \\
\text { content, } \\
\mu \mathrm{g} / \mathrm{kg}\end{array}$ & $\begin{array}{l}\text { Bens(a)pyrene } \\
\text { increase } \\
\text { frequency from } \\
\text { oil pollution }\end{array}$ & $\begin{array}{c}\text { Content of } \\
\text { oil } \\
\text { substances, } \\
\mu \mathrm{g} / \mathrm{kg}\end{array}$ \\
\hline \multirow{3}{*}{$\begin{array}{l}\text { Uncontaminate } \\
\text { d soil (control) }\end{array}$} & $0-15$ & $0.70 \pm 0.25$ & - & 0 \\
\hline & $15-30$ & $1.50 \pm 0.53$ & - & 0 \\
\hline & $30-45$ & $5.30 \pm 1.90$ & - & 120 \\
\hline \multirow{3}{*}{$\begin{array}{c}\text { Oil- } \\
\text { contaminated } \\
\text { soil }(\mathrm{OCS})^{*} \\
\end{array}$} & $0-15$ & $390 \pm 97$ & 557 & 23800 \\
\hline & $15-30$ & $210 \pm 50$ & 140 & 12500 \\
\hline & $30-45$ & $360 \pm 90$ & 68 & 10900 \\
\hline MPC & - & 20 & - & - \\
\hline
\end{tabular}

Note: * - soil sampling was performed 365 days after contamination.

They may be of natural origin, i.e. bituminous substances of soil, or may be the result of the influx of some petroleum substances from neighboring fields as a result of the diffusion of light hydrocarbons.

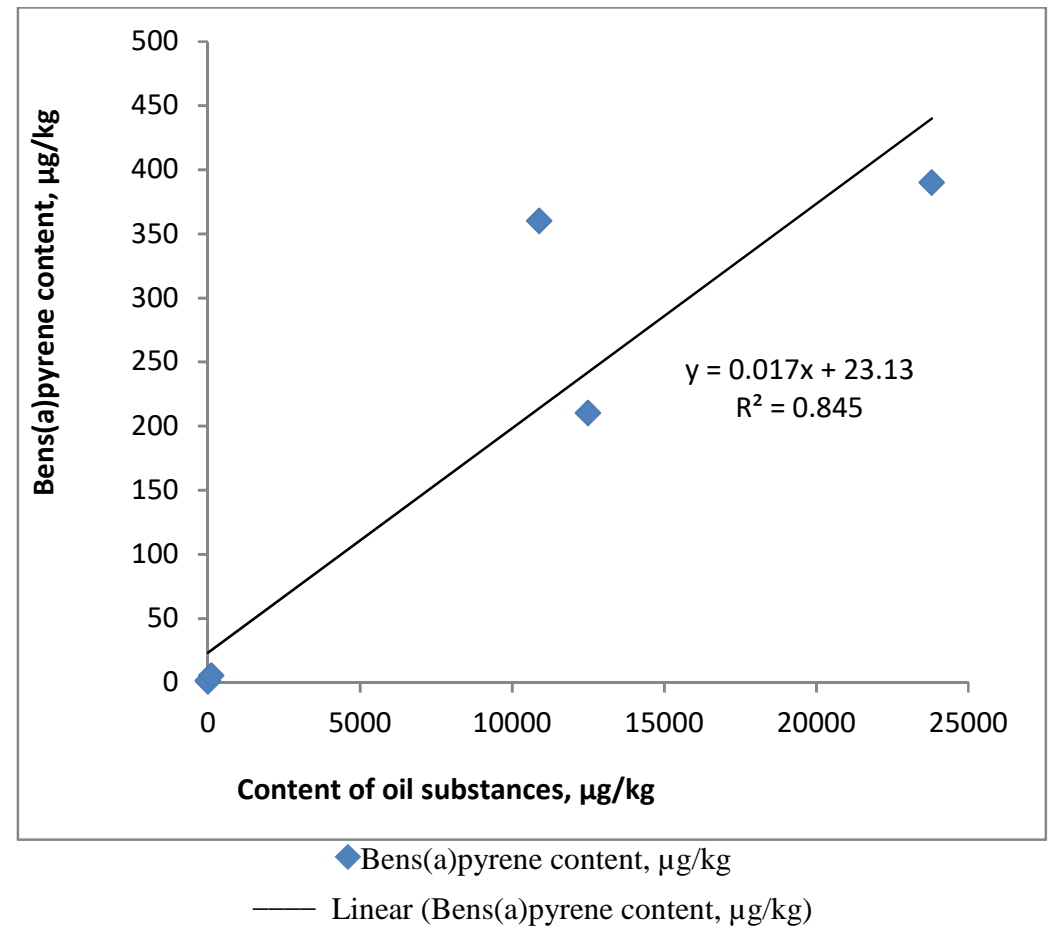

Fig. 1. Dependence of bens(a)pyrene content on the level of grey forest soil contamination with oil 
The deliberate contamination of soil with commercial oil at a rate of $25 \mathrm{l} / \mathrm{m}^{2}$ a year ago led to an excessively sharp increase in bens(a)pyrene. In layers of 0-15, 15-30 and $30-45 \mathrm{~cm}$ of the contaminated soil the BP content made $390 ; 210$ and $360 \mu \mathrm{g} / \mathrm{kg}$ of soil, which is $19.5,10.5$ and 18.0 times higher the MPC, respectively. When comparing the $\mathrm{BP}$ content in individual layers in background and oil-contaminated soils, an interesting pattern of BP content increase is found: a very significant decrease in the frequency of BP increase in contaminated soil as it deepens into the soil profile. Compared to the background in contaminated soil, the content of BP in the uppermost layer exceeds by 557 times, and in 15-30 and 30-45 cm layers - by 140 and 68 times respectively.

These figures illustrate a close positive dependence of the content of bens(a)pyrene in the soil horizons on the content of petroleum substances in them. The coefficient of determination $\left(R^{2}\right)$ of bens(a)pyrene quantity $(U)$ on the amount of oil substances $(x)$ in the corresponding layers made 0.845 , and the correlation between these two indicators was described by the linear dependence equation: $\mathrm{U}=0.017 \cdot \mathrm{x}+23.13$.

\section{Conclusion}

There were different changes in the food regime of grey forest soil under the influence of oil contamination. If the content of most labile forms of nutrients (nitrogen, phosphorus, potassium, boron, molybdenum, zinc) has decreased, the content of labile forms of three microelements has either not changed (copper, cobalt) or increased (manganese) under the influence of oil contamination. At the same time, these changes were not as significant since the groups of grey forest soil supply with labile forms of nutrients did not change under the influence of oil, except phosphorus and potassium. Only the degree of oil-contaminated soil supply with phosphorus and potassium was one group lower than the control soil.

The nature and extent of the change in the content of bens(a)pyrene due to oil pollution was fundamentally different from those of food regimes. There was a close positive linear dependence $\left(\mathrm{R}^{2}=0.845\right)$ of $\mathrm{BP}$ content on the amount of petroleum substances in the grey forest soil. Under the influence of commercial oil at a rate of $25 \mathrm{l} / \mathrm{m}^{2}$ a year ago, the BP content in oil-contaminated soil horizons increased to $210-390 \mu \mathrm{g} / \mathrm{kg}$, which is 10.5-19.5 times higher than MPC. Therefore, the content of bens(a)pyrene seems to be extremely important for objective agrochemical and agroecological assessment of the fertility level of oil-contaminated grey forest soils.

\section{References}

1. N.P. Solntseva. Oil production and geochemistry of natural landscapes (MSU publ. house, Moscow, 1998), $376 \mathrm{p}$.

2. M.Yu. Gilyazov, I.A. Gaisin, Agroecological characteristics and methods of recultivation of oil- contaminated chernozem of the Republic of Tatarstan (Fen, Kazan, 2003), 228 p.

3. A.V. Lednev, Changing the soil properties of the European part of the Non-chernozem zone of the Russian Federation under the influence of oil products and methods of their remediation (Zifra, Izhevsk, 2018), 229 p.

4. Five-fold increased damage from oil pollution, Retrieved from: https://oilcapital.ru/news/markets/ 17-02-2020/pyatikratno-vozros-uscherb-otzagryazneniya-nefteproduktami-v-2018-godu.

5. M. Gilyazov, R. Osipova, A. Ravzutdinov, S. Kuzhamberdieva, Yield and Chemical Composition of Spring Wheat Harvest on Oilcontaminated Grey Forest Soil, in: Int. sci. and pract. Conf. "AgroSMART - Smart solutions for agriculture”, pp. 338-346 (KnE Life Sciences, 2019)

6. V.M. Nazaryuk, M.I. Klenova, F.R. Kalimullina, Role of mineral nutrition in increasing plant productivity and regulating the food regime of oilcontaminated soil, Agrochem. 7, 64-73 (2007)

7. A.P. Uzoije, J.C. Agunwamba, Physiochemical Properties of Soil in Relation to Varying Rates of Crude Oil Pollution, J. of Environmental Science and Technol. 4, 313-323 (2011)

8. Y. Wang, J. Feng, Q. Lin, X. Lyu, X. Wang, $\mathrm{G}$. Wang, Effects of crude oil contamination on soil physical and chemical properties in Momoge wetland of China, Chinese Geograph. Sci. 23(6), 708-715 (2013)

9. T.S. Voevodina, A.M. Rusanov, A.V. Vasilchenko, Influence of oil on the chemical properties of chernozem of the common southern the piedmont of the western Urals, J. of Orenburg State Univer. 10, 157-160 (2015)

10. A.I. Fateev, N.N. Miroshnichenko, E.V. Panasenko, S.I. Khristenko, Change of agrochemical and microbiological properties of oil-contaminated chernozem during the recultivation period, Agrochem. 10, 53-60 (2004)

11. A.V. Lednev, A.V. Lozhkin, Effect of oil pollution on agrochemical and toxicological indices of sodpodzolic soils, Agrochem. 2, 72-78 (2019)

12. L.M. Shabad, Circulation of carcinogens in the environment (Medicine, Moscow, 1973), 295 p.

13. T. Sanneret et al., Potency grading in carcinogen classification, Molecular carcinogenesis 20, 280-287 (1997)

14. N.A. Kireeva, E.I. Nowelova, N.I. Erokhina, A.S. Grigoriadi, Accumulation of benz(a)pyrene in the soil-plant system in case of oil pollution and active sludge introduction, J. of Orenburg State Univer. 6(100), 579-581 (2009)

15. B.A. Dospekhov, Experimentation technique, 5rd ed., revised and amended (Agropromizdat, Moscow, 1985), $351 \mathrm{p}$. 
16. Methodological guidelines for integrated monitoring of soil fertility of agricultural lands (Rosinformagrotech, Moscow, 2003), 240 p.

17. L.I. Belykh, I.A. Ryabchikova, V.A. Seryshev, Patterns of benz(a)pyrene distribution in the soils of agroecosystems of Southern Baikal region, Agrochem. 4, 65-72 (2004)
18. N.E. Kosheleva, E.M. Nikiforova, Long-term dynamics and factors of benz(a)pyrene accumulation in urban soils (on the example of the Eastern Administrative District of Moscow), Bull. of Moscow Univer. Ser. 17 Soil Sci. 2, 25-34 (2011) 